\title{
Impact of Organizational Innovation on Work Performance: The Mediating Effect of Work Resources in Public-Sector Organizations
}

\author{
Janiscus Pieter Tanesab \\ Doctoral Candidate in Public Administration \\ Graduate School of Governance-Sungkyunkwan University \\ 25-2, Sungkyunkwan-ro, Jongno-gu, 03063 \\ Seoul-Republic of Korea
}

Jun Jung Park

Doctoral Student in Political Science and Public Administration

At the Department of Policy Studies, Hanyang University Graduate School,

Wangsimni-ro, Seongdong-gu, 04763

Seoul-Republic of Korea

\begin{abstract}
This paper presents relationships between organizational innovation and organizational work performance mediated by work resources of the Korean public-sector organizations. Previous studies have addressed innovation performance. This study aimed to find the causal-effect relationships among those constructs through work resources that empowered the impact on the organizational work performance as the outcome. The issue of public-sector organizations in terms of organizational innovation, work resources and organizational work performance are discussed, and the variables are briefly explained in the study. Through the survey data from Korean Institute of Public Administration (KIPA), we applied structural equation modeling to analyze the data. The results found that organizational innovation positively influenced organizational work performance, which was triggered by the mediation effect of organizational work resources in Korean public-sector organizations. Finally, the implications and contributions are discussed.
\end{abstract}

Keywords: Innovation, work resources, work performance, public-sector organization.

\section{Introduction}

Innovation promotes changes within public-sector organizations. And organizational innovation implements unusual practices (Altshuler \& Zegans 1997) and new ideas that recognizes a practical impact through new changes within the organization (Hartley 2005). Innovation is deemed as an essential factor that influences the success of organizations.

Facing the rapid changes of information society forces organizations to innovate for survival; hence, innovation is considered as the magic ingredient that triggers, inspires, and likely enables organizations to sustain and develop (Chen et al. 2015). Technology innovation contributes to both internal as well as external organizational activities. And so, innovative organizations are more flexible and respond promptly to change. The components of innovate organizations expand the horizons when they create new opportunities (Drucher 1984; Naranjo-Valencia et al. 2016).

Moreover, innovation is triggered by work resources that consists of human, physical, and information resources to progress. Enhancing the development of work resources and capabilities may affect the organizational performance (Nieves \&Quintana 2018). Thus, this paper aims to establish whether performance work resources posit the mediating functions to explain the relationship between organizational innovation and organizational performance, - in this matter is not just on the firm performance (Chen et al. 2020), but also in the context of public-sector organizations. The research also addressed work performance itself as the outcome of the organizational innovation in public-sectors. Work performance consists of the activities that are performed to attain the objectives of the organization (Motowidlo et al. 1999; Jayaweera 2015). To achieve a better work performance, organizations are required to innovate by harnessing knowledge, skills, abilities, opportunities, and willingness of employees to innovate (Hartley 2005).

Previous studies have applied the mediating role of human capital respecting human resource management and performance, which primarily focused on the manufacturing sector, and less studies to public service sector (Nieves \& Quintana 2018). 
Moreover, lack of research on work resources conducted as mediator for the association of organizational innovation to the organizational work performance in public-sector organizations to develop organizational work environment. As Rainey (2014) argued that environmental factors, including political, economic, cultural, and technological aspects, influence the conditions of organizational management (see also Park \& Kim 2013). And so this research is pivotal to address. Thus, to be more efficient, this study is limited to performance work resources (e.g., available human resources, physical, and information resources).

This current research is examining the impact of the organizational innovation on the organizational work performance by focusing on work resources in the context of the Korean public-sector organizations. This is to bridge the existing research gap which ultimately seeks to explore the relationships between organizational innovation and organizational performance as the outcome.

In addition, the organizational innovation enhances public employees' performance, both directly and indirectly, by sustaining resource innovation (Azar \& Ciabuzchi 2017). Organizational innovation requires innovate work resources that impact on the effective organizational performance. In this regard, studies on work resources as the mediator that links the relationships between organizational innovation and organizational work performance have rarely been undertaken on public-sector organizations. Therefore, this research sought to explore the following questions: 1) Is there any direct influence of the organizational innovation on the organizational work performance?; and 2) Is there any mediating effect of work resources towards both organizational innovation and organizational work performance?

Referring to the rationale, the aim of the study is to test the relationship between organizational innovation and the organizational work performance as the outcomes, and the contribution of the mediation of work resources in the Korean public-sector organizations. After the introduction, this paper addressed the literature reviews as the theoretical framework, and proposes the related hypotheses development. In the methods section, we provide the measurement techniques and an analysis strategy, followed by the results of the analysis. The paper then concludes a brief discussion; Theoretical, and practical implications are also addressed.

\section{Theoretical Background}

\subsection{Organizational Innovation}

Innovation is defined from various perspectives related to the contexts of every community segment; - but basically in the organizational contexts, it is the implementation of new organizational methods in practices, workplace, and external relationships of organizations (Organization for Economic Co-operation and Development [OECD] 2005; Camison \& Villar-Lopez 2014). In this matter, innovation entails generating new concepts into practices in an organization. Referring to process theory, environmental factors, such as technology for innovation, would influence the employees' motivation to be equipped with the knowledge and skills needed to perform tasks and provide organizations with chances to reinforce values, attitudes, and behaviors (Mustafa et al. 2015). This process can lead to the desired outcomes when public-sector employees dedicate their capacities to serve the community.

Innovation then is triggered by a sustainable competitive advantage, which determines the capability of the organization to constantly renew its valuable resources (Eisenhardt \& Martin 2000; Grant 1996; Nelson \& Winter 1982; Teece et al. 1997; Winter 2000; Camison \& Villar-Lopez 2014). Camison \& Villar-Lopez (2014) stated that technological innovation included process, and product innovation, while non-technological innovation involves marketing, and organizational innovation. Therefore, this study contributes to the aspect of the organizational innovation in public-sector.

Damanpour and Aravind (2012) argued that organizational innovation is a fundamental strategic investment for the development of sustainable competitive advantage (Camison \& Villar-Lopez 2014). Similarly, Peters and Waterman (1982) said that it is a means for organizations to respond to dynamic environmental changes (Ho 2011). Vigoda-Gadot et al. (2005) noted that innovation becomes a multidimensional trait of organizations and includes creativity, risktaking, openness to change, future orientation, and pro-activeness (Ho 2011). Even though innovation scholars have stressed the importance of organizational innovation for performance, there is still lack of investigations regarding these relationships through a provision of the available organizational work resources.

\subsection{Organizational Work Resources}

Work resources must be appropriately managed on the basis of skills and abilities for the adequate development of an organization. Previous scholars argued that human capital is vital for maximizing the capacities of an organization (Cheng \& Huang 2009; Lopez-Cabrales et al.2009; Youndt \& Snell 2004; Nieves \& Quintana 2018). Regarding human resource aspect, when studying performance innovation relationships, it is important to consider other physical resources like technology, and also organizational management together (Nieves \& Quintana 2018). 
An understanding of work resources can be achieved by specifically examining the influence of organizational innovation on the adopted resources, such as technological innovation which may influence the performance of an organization in certain ways.

The socio-technical system theory asserts that a change in organizational resources, like technological system, requires changes in the management system to adjust its demand (Azar \& Chiabuschi 2017). Organizational innovation in this matter is the precondition for the work resources that need to be provided and implemented. The integration of a single or multiple-type of innovation requires better knowledge about how organizations should deal with changes facing uncertainties in their environment to achieve a superior organizational performance (Damanpour \& Arivand 2012; Nieves \& Quintana 2018).

Subramaniam and Youndt (2005) argued that capable employees can achieve plenty of skills, and more open to acquire new knowledge, improve organizational capacity, and promote new ways of thinking (Nieves \& Quintana 2018). Individuals with adequate knowledge, abilities, and experience are the main resources of an organization (Nieves \& Quintana 2018). Therefore, the successful implementation of innovation work resources depends on promoting administrative changes for organizational innovation (Damanpour et al. 1989; Azar \& Chiabuschi 2017).

\subsection{Organizational Work Performance}

Performance indicates the image and prospects of the organizational development. And so work performance influences on the benefits the organization. Performance deals with an employee's capacity to succeed by accomplishing tasks as a source of satisfaction (Muchal 2014; Jayaweera2015). Rainey (2014) stated that there are some factors like motivation, ability, preparation, training, and perception of the ability to perform that clearly influence organizational performance (Park \& Kim 2013).

Performance cannot be separated from work effectiveness in public-sector organizations. Work effectiveness is a multidimensional construct that precedes performance. Effectiveness refers to outcome and output measures. Outputs are the immediate results of organizational activities, while outcomes are the extent of the measures related to the ultimate objectives of the organization (Berman 2006; Joaquin \& Park 2013; Park et al. 2014). Effectiveness in publicsector organizations involves outputs, innovativeness in services and processes, responsiveness, and accountability that includes community satisfaction (Joaquin \& Park 2013; Park et al. 2014). It also involves employee outcomes related to job satisfaction, organizational commitment, and organizational civic behavior.

\subsection{Hypothesis Development}

\subsubsection{Organizational Innovation and Work Performance}

Innovation refers to the implementation of novel ideas into practices through new improved products and services as well as putting new marketing or organization methods into business practices and organizational workplaces (OECD 2005; Naranjo-Valencia et al. 2016). Studies argued that there are three innovation categories: product, process and management innovation (Damanpour1991; 1996; Ali et al. 2016). Product innovation involves the introduction of improved goods or services with regard to the beneficiaries; Process innovation brings new elements to the organizations to improve production or service processes. Then, management innovation introduces new organizational methods in workplace practices and a connection to the environment. Moreover, the OECD (2005) reported that regardless of those categories of innovation, management innovation is categorized as both organizational and marketing innovation (Naranjo-Valencia et al. 2016). Organizational innovation involves the implementation of new organizational methods in the work place or external relations, - while marketing innovation encompasses the implementation of new marketing methods that include product design and packaging, promotion and placement, and changes for pricing goods and services.

The interrelationship of process, product, and management innovation expresses a deeper understanding of the organizational performance (Jimenez-Jimenez \& Sanz-Valle 2011; Camizon \& Villar-Lopez 2014; Ali et al. 2016). Those innovative dimensions are linked together to attain organizational goals.

Regarding rapid external environmental changes, organizations need to cope with increasing complexity and shifting facing uncertainties. Therefore, organizations with the capability to adapt, change, and develop will be able to endure and improve new products or services than noninnovative organizations (Jimenez-Jimenez et al. 2008; NaranjoValencia et al. 2016) that perpetuates status quo. Furthermore, scholars have addressed studies on the effect of the organizational innovation on the organizational performance (Mazzanti et al. 2006;

Mol \& Brikinshaw 2009; Camison \& Villar-Lopez 2014). Zhang also demonstrated that there is a positive relationship between innovation and job performance (2011; Naranjo-Valencia et al. 2016).

Researchers also have addressed that processes, products, and administrative innovation jointly influence organizational performance (Jimenez-Jimenez \& Sanz-Valle 2011; Camizon \& Villar-Lopez 2014; Ali et al. 2016). 
However, from those findings, still lack of research addressing the relationship between organizational innovation and organizational work performance within the context of public sector-organizations whether in central as well as in local government organizations. Therefore, we proposed the following hypothesis:

Hypothesis 1: Organizational innovation is positively associated with organizational work performance in public-sector organizations contexts.

\subsubsection{Organizational Innovation and Work Resources}

Innovation is a way to integrate relationships among job components in an organization. Studies have identified creativity and innovation as critical variables for the success of organizational innovative performance (Choi 2004; Lin \& Liu 2012). Redmond et al. (1993) stated that empowered employees generate new ideas using the relevant knowledge, skills, and abilities to overcome various organizational problems, and they gain a sense of accomplishment by doing so ( $\mathrm{Li}$ et al. 2015). Lin \& Liu (2012) posited a job characteristic theory which predicted that, under certain conditions, valued individuals who had experience in certain jobs concerning skills, task identity, task significance, autonomy, and feed-back were more likely to perform better, achieve greater productivity, and attain higher levels of performance satisfaction.

Individual innovative capacities as resources to draw upon regarding ability, education, training, and practical experience are more likely to work in innovative ways (Hayton \&Kelly 2006; Nieves \& Quintana 2018). Organizational innovation creates an accepting and relevant environment that facilitates the adoption of work resources that simultaneously can enhance organizational performance (Damanpour \& Evan 1984; Damanpour et al. 1989; Azar \& Chiabuschi 2017). Nevertheless, research on the mediating effect of work resource performance regarding the relationship between organizational innovation and organizational work performance has not broadly investigated within public-sector organizations. Scholars also argued that the importance of organizational innovations concerning changes in work resources is still underappreciated (Damanpour \& Evan1984; Azar \& Chiabuschi 2017). Thus, to strengthen this gap, we assumed that:

Hypothesis 2: Work resources positively mediate the association between the organizational innovation to organizational work performance in public-sector organizations.

\subsubsection{Work Resources and Organizational Work Performance}

Work performance determines the quality and quantity of individual or group work achievement (Schermerhorn et al. 2002; Ho 2011). It deals with working condition which is indicated by the contribution of work resources. Good working conditions can lead to great work performance and can also be a strong motivation to improve work performance (Jayaweera 2015).

Organizational performance is the indicator of how well organizations achieve their objectives based on the effectiveness of human and physical resources (Hamon 2004; Robins \&Coulter 2002; Ho 2011). Nieves and Quintana (2018) found that work resources influence organizational performance by strengthening employees' skills and positive behavior for better organizational performance. The available work resources contribute significantly to effective organizational performance.

$\mathrm{Wu}$ also argued that the greater the asset of human capital, the greater the opportunity for knowledge exchange and combination of process development to the organizational performance (2004; Nieves \&Quintana 2018). Likewise, Jiang et al. stated that when organizations have higher-quality human capital they are more capable of achieving innovation and good performance (2012; Nieves \&Quintana 2018). Thus, after having innovative work resources from the organizational innovation such people and technological resources, then, we assumed that the organizational work performance might be more effective in public-sector organizations. Therefore, we partially proposed the following assumption that:

Hypothesis 3: Organizational work resources are positively related to organizational work performance. 


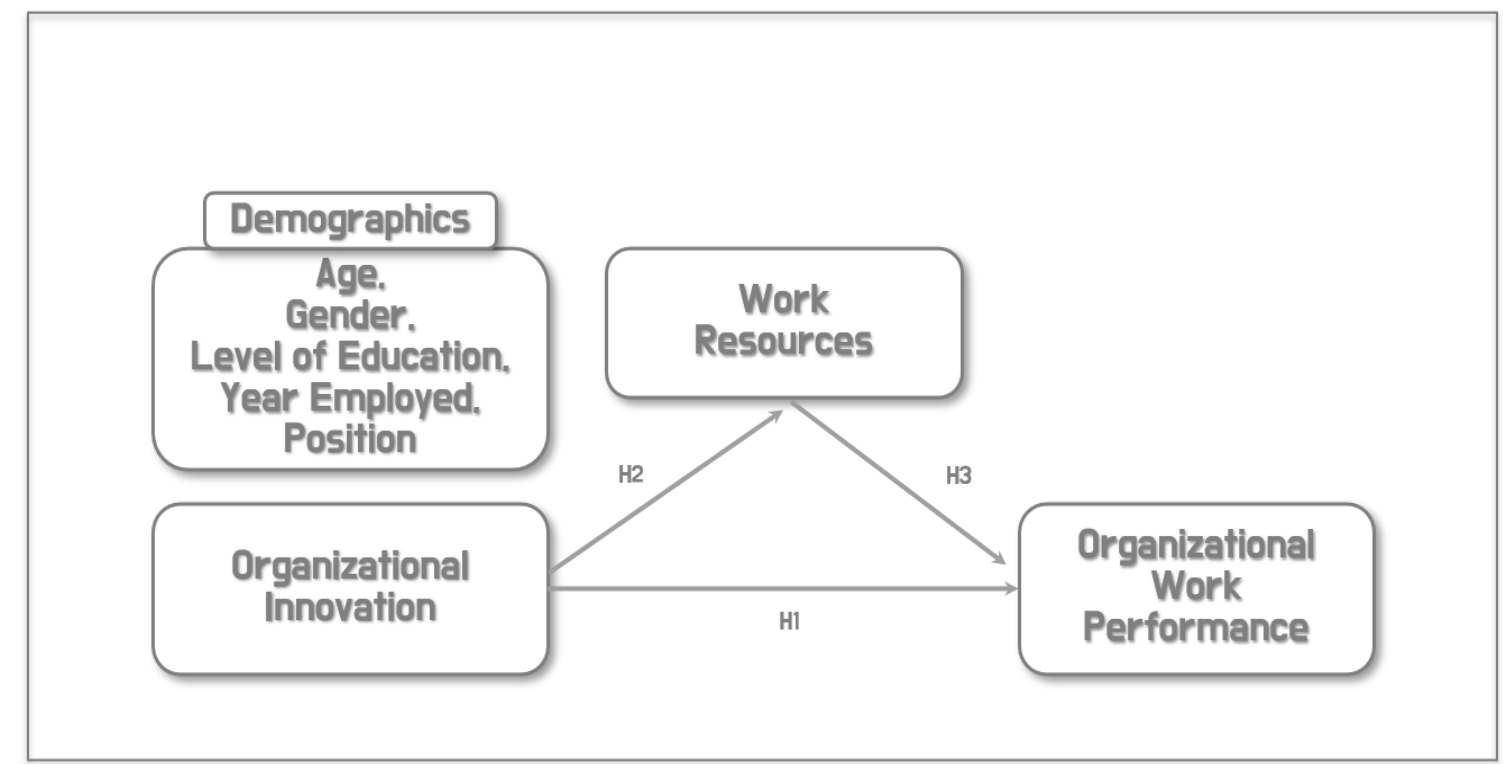

Figure 1: The conceptual model

\section{Research Method 3.1 Research Setting}

The study used survey data from Public Employee Perception Survey of Korean Institute of Public Administration (KIPA) August 2016, as the collection tool. The survey study was applied to 2070 respondents comprising 1,340 (64.7\%) participants from 42 central administrative agencies, and 730 (35.3\%) participants from 17 local administrations in South Korea's public-sector organizations.

Sampling and Data Collection

A total of 2070 valid responses were taken to conduct the study, comprising $80.0 \%$ participants as civil servants from central administrative agencies and $20.0 \%$ from local governments. The survey questionnaire consisted of 9 items in total for organizational innovation, work resources, and organizational performance. 
Table 1. Sample characteristics $(\mathrm{n}=2070)$

\begin{tabular}{|c|c|}
\hline Variables & $\%$ \\
\hline \multicolumn{2}{|l|}{ Gender } \\
\hline Male & 63.4 \\
\hline Female & 36.6 \\
\hline \multicolumn{2}{|l|}{ Age (years) } \\
\hline $20-29$ & 9.2 \\
\hline $30-39$ & 39.5 \\
\hline $40-49$ & 38.4 \\
\hline 50 and above & 12.9 \\
\hline \multicolumn{2}{|l|}{ Current Position } \\
\hline Grade 9 & 4.9 \\
\hline Grade 8 & 7.8 \\
\hline Grade 7 & 28.8 \\
\hline Grade 6 & 28.8 \\
\hline Grade 5 & 22.6 \\
\hline Grade 4 & 5.7 \\
\hline Grade 3 & 1.3 \\
\hline Grade 2 & 0 \\
\hline Grade 1 & 0 \\
\hline \multicolumn{2}{|c|}{ Current Educational Attainment } \\
\hline High School or less & 2.9 \\
\hline College (2-3 years) & 5.5 \\
\hline Bachelor's Degree & 72.4 \\
\hline Master's Degree & 17.6 \\
\hline Doctorate & 1.6 \\
\hline \multicolumn{2}{|l|}{ Type of Organization } \\
\hline Central & 64.7 \\
\hline Local & 35.3 \\
\hline
\end{tabular}

Constructs were measured using multiple item scales. Those items were measured by applying the Likert scale, with the end-points ranging from strongly disagree (1) to strongly agree (5). The analysis adapted structural equation modeling to test the proposed hypotheses. 
Organizational Innovation; three items were selected from the existing studies to measure aspects of organizational innovation. Sample items included the following: our organization is flexible and responds instantly to change; our organization accepts some risk for innovation; and change in our institution usually has a positive effect. Cronbach's alpha for these organizational innovation factors was .854 .

Work resources, was measured by a three-item scale: I am appropriately provided with human resources; I am appropriately provided with physical resources; I am appropriately provided with information resources. The Cronbach's alpha for work resource factors was .828.

Organizational work performance, was measured by three items: our organization is striving to reduce costs; the performance of our institution has been steadily improving; the performance and quality of our institution is improving. Cronbach's alpha for organizational performance factors was .862 .

Moreover, the effects of demographic factors such as employee's age, gender, education, year of employment, and tenure, which could affect organizational performance, were controlled for. The results of this study showed consistency with or without their inclusion (Mostafa et al. 2015).

\subsection{The Analysis}

The study applied structural equation modeling through a two-step approach: estimating the measurement model and the structural model. The entire models were estimated to minimize the standard error by applying maximum likelihood with bootstrapped standard errors. Confirmatory factor analysis assessed the factor structure, reliability, and validity for the three latent variables.

\section{Measurement Model}

In terms of measurement model, the factor loading ranged from .801 to .875 , which was above the threshold of .60. The Kaiser-Meyer-Olkin (KMO) measure of sampling adequacy was equivalent to $.822(p<.000)$. By conducting confirmatory factor analysis, we performed the difference among constructs found in the model to a proper fit among the constructed model. The comparative fit index (CFI) was .994 (>.95); the standard root mean residual (SRMR) was .021 (<.08); and the root mean square of approximation (RMSEA) was .035 (<.08); PClose was 0.999 (>.05). Overall, these results were interpreted as excellent since they were greater than the minimum threshold for each. Measurement on discrimination validity of constructs model found that internal consistency index (CR) was greater than .880, which is above the threshold of .70, and the average variance extracted was above .711, which is above the threshold of .50.

The correlation coefficient based on the descriptive statistics (mean and standard deviation) between constructs of the model showed that the correlations among variables are relatively strong $(\mathrm{p}<.001)$. In other words, organizational innovation is strongly correlated with organizational work performance and the mediation effect of performance work resources supported the relationship among variables.

Figure 2: Confirmatory Factor Analysis

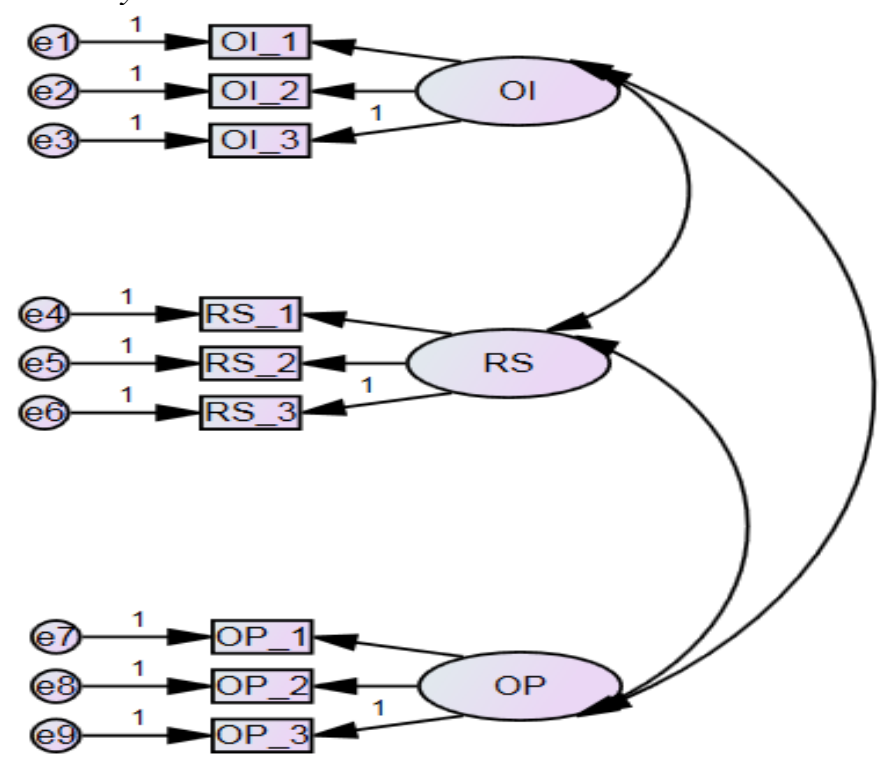


Table 2. The result of factor analysis, reliability and validity of the measurement

\begin{tabular}{|c|c|c|c|c|c|c|}
\hline \multirow{2}{*}{ Items } & \multicolumn{3}{|l|}{ Factors } & \multicolumn{3}{|c|}{ Reliability and Validity Measures } \\
\hline & Work. R & Org. I & Org. P & Cronbach's $\alpha$ & CR & AVE \\
\hline RS_1 & .873 & & & & & \\
\hline RS_2 & .844 & & & .828 & .880 & .711 \\
\hline RS_3 & .825 & & & & & \\
\hline OI_1 & & .875 & & & & \\
\hline OI_2 & & .841 & & .854 & .905 & .756 \\
\hline OI_3 & & .801 & & & & \\
\hline OP_1 & & & .866 & & & \\
\hline OP_2 & & & .839 & .862 & .923 & .803 \\
\hline OP_3 & & & .829 & & & \\
\hline
\end{tabular}

Table 3. Descriptive statistics and correlations of variables

\begin{tabular}{llllll}
\hline & Mean & $S D$ & Work. R & Org. I & Org. P \\
\hline Work. R & 3.09 & .70 & - & & \\
Org. I & 3.51 & .65 & $.305^{* *}$ & - & - \\
Org. P & 3.11 & .69 & $.335^{* *}$ & $.504^{* *}$ & -
\end{tabular}

** Correlation is significant at the 0.01 level (1-tailed).

\section{Hypothesis Testing and Discussion of Findings}

Estimation and fit indices were calculated in the structural equation modeling. The results revealed a good fit index: $\mathrm{CFI}=.990 ; \mathrm{RMSEA}=.032 ;$ and $\mathrm{CMIN} / \mathrm{DF}=3.067$. The model was thus considered suitable for the data. So we found a highly significant association between the organizational innovation to the organizational work performance of the Korean public-sector organizations which has much developed. It was admitted that the organizational innovation was not only improving the existing routines and practices, but also it develops and assimilate novel thoughts, new skills, adaptive technologies and capabilities (Chen et al. 2020), within public employees of the Korean public-sectors. Thus, hypothesis 1 was supported.

We then examined work resources as the mediating factor in organizational innovation and organizational work performance. We tested the organizational work resources through human resources, physical, and information resources among public-sector employees. The result showed that work resources were a positive mediating factor in both organizational innovation and organizational work performance. To the recent study in comparison, previous scholars found that technological innovation capabilities partially mediated the association between organizational innovation to the organizational performance (Chen et al. 2020). Technological capabilities alone definitely are not sufficient. Work resources are strengthened by the organizational capabilities whether tangible or intangible resources to better organizational performance (Grant 1991; Rehman et al. 2019). The public employee's innovation and creativity are essential parts of the organizational innovation (Higgins 1995; Zhao et al. 2020). Moreover, employee's active participation also plays meaningful function to the performance work system (Zhou et al. 2019) based on the principle of equity that organizational members are treated fairly in the allocation of resources (Adams 1965; Oh 2019), - as also work resources through novel ideas and creativities into the better organizational work performance. And so, the mediating effects of work resources comprising people, process, and technology within public-sector organizations are crucially pivotal. Therefore, the finding supported hypothesis 2 of the study.

Finally, it was found that capacities of work resources significantly impacted on the organizational work performance of public-sector organizations. And this is essentially related to organizational capabilities whether individual as well as organizational to develop innovate works and creativities for the organizational innovative performance. 
The study of Zhao et al. (2020) also found that individual creativity has direct and significant impact on the organizational innovation performance. Subsequently, work resources are stemmed from employees' knowledge resources. These resources are asset to serve and facilitate knowledge sharing activities through the contribution of technology and exploration of new knowledge (Garcia et al. 2003; Oh 2019). Thus, the assumption (H3) of this study was also supported.

Figure 3. Structural Equation Modeling

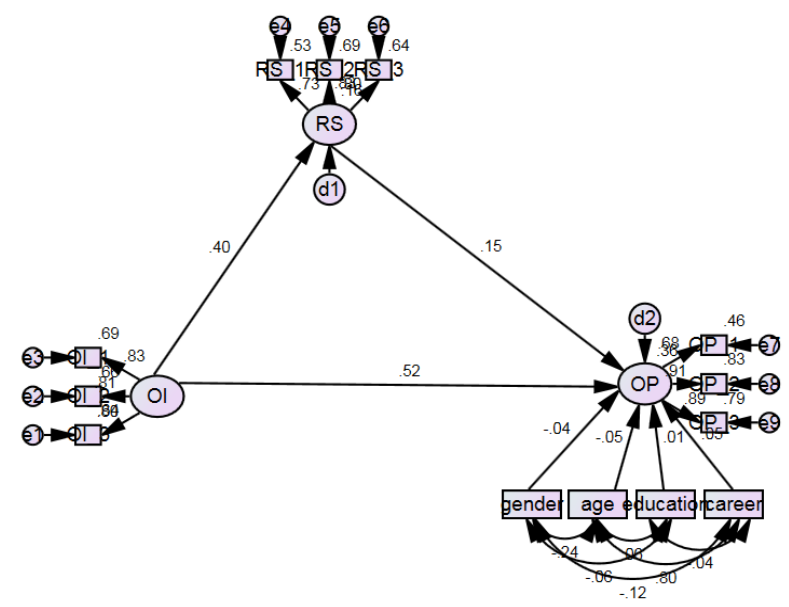

Table 4.SEM and Mediating effect results

\begin{tabular}{|c|c|c|c|c|c|c|}
\hline & & & Estimate & S.E. & C.R. & $\mathrm{P}$ \\
\hline Org. Innovation & $\rightarrow$ & Resource & .389 & .026 & 14.752 & $* * *$ \\
\hline Org. Innovation & $\rightarrow$ & Org. Performance & .443 & .024 & 18.41 & $* * *$ \\
\hline Resource & $\rightarrow$ & Org. Performance & .129 & .021 & 6.073 & $* * *$ \\
\hline Gender & $\rightarrow$ & Org. Performance & -.042 & .022 & -1.91 & .056 \\
\hline Age & $\rightarrow$ & Org. Performance & -030 & .021 & -1.403 & .161 \\
\hline Educ. now & $\rightarrow$ & Org. Performance & .10 & .016 & .623 & .533 \\
\hline Career & $\rightarrow$ & Org. Performance & -.016 & .010 & 1.59 & .111 \\
\hline
\end{tabular}

\section{Conclusion}

The purpose of this study was to examine the causal effect relationship of organizational innovation and organizational work performance. The study found positive relationships among those variables, indicating that organizational innovation for public-sector employees has a significant influence on improved organizational work performance in the Korean public-sector organizations. Similarly, organizational innovation posits as strategic asset and powerful strength of the organization to enhance sustainable competitive development and greater performance in public-sector organizations (Camison \& Villar-Lopez 2014; Singh et al. 2019). Likely, organizations that are high in organizational innovations have a higher level of implementation of ideas (Damanpour 1996; Chen et al. 2020) to a better organizational performance. 
Moreover, performance of work resources was positive mediating factor in both organizational innovation and organizational work performance; while also function as the antecedent to the improved organizational work performance in public-sector organizations. The improved of organizational resources and capabilities could enhance the organizational performance (Rehman et al. 2019) because of the trigger of the innovative performance. And work resources should be supported by values of organizational resources by managing them effectively to enhance the organizational performance in public-sector organizations (Sirmon \& Hitt 2003; Sirmon et al. 2007; Rehman et al. 2019).

Overall, our findings are consistent with our hypotheses. The causal effect relationship of organizational innovation to organizational work performance is greatly significant; - as it is performed through the meaningful mediation effect of performance work resources in the Korean public-sector organizations.

\section{Theoretical and Practical Implication}

The results of the current research contribute to previous works showing an association between organizational innovation and organizational performance (Mazzanti et al.2006; Mol \& Brikinshaw2009; Camison \& Villar-Lopez (2014) in public sector organizations. Practically, has addressed the empirical work that organizational innovations within the Korean public-sector organizations has led greater progressive innovative development to a better organizational work performance.

This study also addressed that work resources and organizational work performance perpetuated strong association between the two.

This was consistent with previous research revealed that organizational innovation creates a suitable environment that impacts the adoption of work resources and enhances organizational performance (Damanpour \& Evan 1984; Damanpour et al. 1989; Azar \& Chiabuschi 2017). The current finding implies that public-sector employees are particularly affected to develop their innovate capacities for effective organizational work performance. And simultaneously, work resources had a mediating effect on the organizational performance. Organizations with higher quality resources are more capable of achieving innovation and greater organizational performance (Jiang et al. 2012; Nieves \& Quintana2018).

\section{Limitations and Suggestions}

The study is limited in several respects. Regarding its significant results, the study merely applied the aspect of innovation at the organizational level as the independent construct. Thus, it is suggested for future study to integrate other influential antecedents for organizational innovation, such as the effect of environmental factors in terms of leadership commitment, culture, demographic changes, etc., which affect the organizational innovation. The focus of this study is also limited to the organizational innovation; therefore, further study may explore other dimensions of the public-sector innovation. Then, based on the given design, our mediating variable applied in this research is limited to work resources in the Korean public-sectors that has much advanced. We suggested to address broader and more adequate resources in other contexts of public-sector organizations.

Finally, our study is based on the survey data which requires current updates; - therefore, future study should adapt the latest one and develop other qualitative our mixed approaches for deeper understanding about organizational innovation and supporting resources for a better organizational performance in public-sector services.

\section{References}

Adams, J.S. (1965), "Inequity in social exchange", in Berkowitz, L. (Ed.), Advances in Experimental Social Psychology, Vol. 2, Academic Press, New York, NY, pp. 267-299.

Ali, M., Kan, K. A. S., \& Sarstedt, M. (2016). Direct and configurational paths of absorptive capacity and organizational innovation to successful organizational performance. Journal of Business Research, 69(11), 5317-5323.

Altshuler, A. A., \& Zegans, M. D. (1997). Innovation and public management: Notes from the state house and city hall. Innovation in American Government, 68-80.

Azar, G., \& Ciabuschi, F. (2017). Organizational innovation, technological innovation, and export performance: The effects of innovation radicalness and extensiveness. International Business Review, 26(2), 324-336.

Berman, E. M. (2006). Performance and productivity in public and nonprofit organizations. Armonk, NY: ME Sharpe.

Camisón, C., \& Villar-López, A. (2014). Organizational innovation as an enabler of technological innovation capabilities and firm performance. Journal of business research, 67(1), 2891-2902.

Chen, C. J., \& Huang, J. W. (2009). Strategic human resource practices and innovation performance-The mediating role of knowledge management capacity. Journal of business research, 62(1), 104-114. 
Chen, Y., Wang, Y., Nevo, S., Benitez-Amado, J., \& Kou, G. (2015). IT capabilities and product innovation performance: The roles of corporate entrepreneurship and competitive intensity. Information \& Management, 52(6), 643-657.

Chen, Q., Wang, C. H., \& Huang, S. Z. (2020). Effects of organizational innovation and technological innovation capabilities on firm performance: evidence from firms in China's Pearl River Delta. Asia Pacific Business Review, 26(1), 72-96.

Choi, J.N. (2004), "Individual and contextual predictors of creative performance: the mediating role of psychological processes", Creativity Research Journal, Vol. 16 Nos 2-3, pp. 187-99.

Damanpour, F., \& Aravind, D. (2012). Managerial innovation: Conceptions, processes, and antecedents. Management and organization review, 8(2), 423-454.

Damanpour, F., \& Evan, W. M. (1984). Organizational innovation and performance: the problem of" organizational lag". Administrative science quarterly, 392-409.

Damanpour, F., Szabat, K. A., \& Evan, W. M. (1989). The relationship between types of innovation and organizational performance. Journal of Management studies, 26(6), 587-602.

Damanpour, F. (1991). Organizational innovation: A meta-analysis of effects of determinants and moderators. Academy of management journal, 34(3), 555-590.

Damanpour, F. (1996). Organizational complexity and innovation: developing and testing multiple contingency models. Management science, 42(5), 693-716.

Drucher, P. F. (1984). The discipline of innovation. Harvard Business Review, 63(3), 67-72.

Eisenhardt, K. M., \& Martin, J. A. (2000). Dynamic capabilities: what are they? Strategic management journal, 21(10-11), 1105-1121.

Garcia, R., Calantone, R. and Levine, R. (2003), "The role of knowledge in resource allocation to exploration versus exploitation in technologically oriented organizations", Decision Sciences, Vol. 34 No. 2, pp. 323-349.

Grant, R. M. (1991). The resource-based theory of competitive advantage: Implications for strategy formulation. California Management Review, 33(3), 114-135.

Grant, R. M. (1996). Prospering in dynamically-competitive environments: Organizational capability as knowledge integration. Organization science, 7(4), 375-387.

Hamon, T. T. (2004). Organizational effectiveness as explained by social structure in a faith-based business network organization.

Hartley, J. (2005). Innovation in governance and public services: Past and present. Public money and management, 25(1), 27-34.

Hayton, J. C., \& Kelley, D. J. (2006). A competency-based framework for promoting corporate entrepreneurship. Human resource management: Published in cooperation with the School of Business Administration, The University of Michigan and in Alliance with the Society of Human Resources Management, 45(3), 407-427.

Higgins, J.M. (1995), "Innovation: the core competence”, Strategy and Leadership, Vol. 23 No. 6, pp. 32-36.

Ho, L. A. (2011). Meditation, learning, organizational innovation and performance. Industrial Management \& Data Systems.

Joaquin, M. E., \& Park, S. M. (2013). Exploring the topography of performance and effectiveness of US federal agencies. Public Personnel Management, 42(1), 55-74.

Jayaweera, T. (2015). Impact of work environmental factors on job performance, mediating role of work motivation: A study of hotel sector in England. International journal of business and management, 10(3), 271.

Jiang, K., Lepak, D. P., Hu, J., \& Baer, J. C. (2012). How does human resource management influence organizational outcomes? A meta-analytic investigation of mediating mechanisms. Academy of management Journal, 55(6), 1264-1294.

Jiménez-Jimenez, D., Valle, R. S., \& Hernandez-Espallardo, M. (2008). Fostering innovation. European Journal of innovation management.

Jiménez-Jiménez, D., \& Sanz-Valle, R. (2011). Innovation, organizational learning, and performance. Journal of business research, 64(4), 408-417.

Li, Y., Wei, F., Ren, S., \& Di, Y. (2015). Locus of control, psychological empowerment and intrinsic motivation relation to performance. Journal of Managerial Psychology.

Lin, C. Y. Y., \& Liu, F. C. (2012). A cross-level analysis of organizational creativity climate and perceived innovation. European Journal of Innovation Management. 
Lopez-Cabrales, A., Pérez-Luño, A., \& Cabrera, R. V. (2009). Knowledge as a mediator between HRM practices and innovative activity. Human Resource Management: Published in Cooperation with the School of Business Administration, The University of Michigan and in alliance with the Society of Human Resources Management, 48(4), 485-503.

Mazzanti, M., Pini, P., \& Tortia, E. (2006). Organizational innovations, human resources and firm performance: The Emilia-Romagna food sector. The Journal of Socio-Economics, 35(1), 123-141.

Mol, M. J., \& Birkinshaw, J. (2009). The sources of management innovation: When firms introduce new management practices. Journal of business research, 62(12), 1269-1280.

Mostafa, A. M. S., Gould-Williams, J. S., \& Bottomley, P. (2015). High-performance human resource practices and employee outcomes: the mediating role of public service motivation. Public Administration Review, 75(5), 747-757.

Motowidlo, S. J., Borman, W. C., \& Schmit, M. J. (1999). Performance assessment in unique jobs. In D.R. Ilgen \& E. D. Pulakos (Eds.), The changing nature of performance (pp. 56-86). San Francisco: Jossey-Bass.

Muchhal, D. S (2014). HR Practices and Job Performance. IOSR Journal of Humanities and Social Science (IOSRJHSS), 19(4), 55-61.

Naranjo-Valencia, J. C., Jiménez-Jiménez, D., \& Sanz-Valle, R. (2016). Studying the links between organizational culture, innovation, and performance in Spanish companies. Revista Latinoamericana de Psicología, 48(1), $30-41$.

Nelson, R. R. y, \& Winter, S. G. (1982). An evolutionary theory of economic change. Cambridge MA and London: The Bleknap Press of Harvard University Press.

Nieves, J., \& Quintana, A. (2018). Human resource practices and innovation in the hotel industry: The mediating role of human capital. Tourism and Hospitality Research, 18(1), 72-83.

OECD (2005). The measurement of scientific and technological activities Oslo Manual. Guidelines for collecting and interpreting innovation data (3rd ed.). Paris: OECD EUROSTAT.

Oh, S. Y. (2019). Effects of organizational learning on performance: the moderating roles of trust in leaders and organizational justice. Journal of Knowledge Management.

Park, S.M. \& Kim, S. (2013). Public Management. A case book. Sungkyunkwan University Press.

Park, Y. K., Song, J. H., Yoon, S. W., \& Kim, J. (2014). Learning organization and innovative behavior: The mediating effect of work engagement. European Journal of Training and Development, 38(1-2), 75-94.

Peters, T., \& Waterman, R. (1982). In search of excellence Harper and Row. New York.

Rainey, H.G. (2014). Understanding and managing public organizations ( $5^{\text {th }}$ ed.). Jossey-Bass.

Redmond, M. R., Mumford, M. D., \& Teach, R. (1993). Putting creativity to work: Effects of leader behavior on subordinate creativity. Organizational behavior and human decision processes, 55(1), 120-151.

Rehman, S. U., Mohamed, R., \& Ayoup, H. (2019). The mediating role of organizational capabilities between organizational performance and its determinants. Journal of Global Entrepreneurship Research, 9(1), 30.

Robbins, S.P. and Coulter, M. (2002), Management, Prentice-Hall, Upper Saddle River, NJ.

Schermerhorn, J.R. Jr, Hunt, J.M. and Osborn, R.N. (2002), Organizational Behavior, Wiley, New York, NY.

Singh, S. K., Gupta, S., Busso, D., \& Kamboj, S. (2019). Top management knowledge value, knowledge sharing practices, open innovation and organizational performance. Journal of Business Research.

Sirmon, D. G., \& Hitt, M. A. (2003). Managing resources: Linking unique resources, management, and wealth creation in family firms. Entrepreneurship Theory and Practice, 27(4), 339-358.

Sirmon, D. G., Hitt, M. A., \& Ireland, R. D. (2007). Managing firm resources in dynamic environments to create value: Looking inside the black box. Academy of Management Review, 32(1), 273-292.

Subramaniam, M., \& Youndt, M. A. (2005). The influence of intellectual capital on the types of innovative capabilities. Academy of Management journal, 48(3), 450-463.

Teece, D. J., Pisano, G., \& Shuen, A. (1997). Dynamic capabilities and strategic management. Strategic Management Journal, 18(7), 509-533.

Vigoda-Gadot, E., Shoham, A., Ruvio, A., \& Schwabsky, N. (2005). Innovation in the public sector. The University of Haifa and NIFU STEP, Oslo.

Winter, S. G. (2000). The satisficing principle in capability learning. Strategic management journal, 21(10-11), 981996.

$\mathrm{Wu}$, J. (2004). Knowledge stock, search competence, and innovation performance in the United States electrical medical device industry. Purdue University.

Youndt, M. A., \& Snell, S. A. (2004). Human resource configurations, intellectual capital, and organizational performance. Journal of managerial issues, 337-360. 
Zhang, M. J. (2011). Firm-level performance impact of IS support for product innovation. European Journal of Innovation Management.

Zhao, S., Jiang, Y., Peng, X., \& Hong, J. (2020). Knowledge sharing direction and innovation performance in organizations. European Journal of Innovation Management.

Zhou, Y., Fan, X., \& Son, J. (2019). How and when matter: Exploring the interaction effects of high-performance work systems, employee participation, and human capital on organizational innovation. Human Resource Management, 58(3), 253-268. 